\title{
Decentralized Urban Planning Challenges in a City of a Developing Country:The Case of Kampala Capital City, Uganda
}

\author{
John Berchmans Barugahare, \\ Department of Architecture and Physical Planning, School of the Built Environment; \\ Makerere University, Uganda
}

\begin{abstract}
Decentralized mode of governance has been adopted by many developing countries since mid-1980s, with the objective of bringing decision making closer to the communities, increase public participation and improve the quality in management. This was lauded as a move away from top-down model of governance to that addressing the local needs at grassroots level. This mode has been fast tracked in Uganda since the late 1980s with urban and district authorities. Among the Urban authorities, Kampala City Council, then a Local Government, took the lead in decentralizing urban planning and land management as by the Local Government Act. Cap 243. For instance a change of administrative set up under the Kampala Capital City Authority Act.2011 revamped service delivery including urban planning. However there was de facto recentralization of urban planning to the centre. This move disenchanfrised the population at the grassroots and gone against the spirit of the constitution of the Republic of Uganda on decentralization. Hence this paper examines the constraints that face decentralization and emphasizes that its role cannot be reversed. Consequently, strategies that can be applied to streamline the process of decentralization and make it functional.
\end{abstract}

Keywords. Decentralisation, urban planning, disenchanfrise, Kampala Capital City Authority

DOI: $10.7176 / \mathrm{JEES} / 9-4-11$

Publication date: April $30^{\text {th }} 2019$

\subsection{Introduction}

Decentralization has been defined as the transfer of responsibility for planning management and allocation of resources from the central government and its agencies, sub-ordinate units or levels of governments, semiautonomous public authorities or corporation, regional area wide or functional authorities (Silverman, 1992; UNHabitat, 2013). Therefore the central theme is transfer of power, authority and delivery of services from central to lower local governments. This involves a multitude of processes as pointed out by the World Bank Decentralization Thematic Team (2001) and Buthelezi (2003), which include political, administrative, fiscal and economic / market. Political decentralization gives citizens and elected representatives more power in decision making. People get involved in the implementation of policies. Decisions are made with wider participation and are relevant to communities' needs. Administrative decentralization gives authority or responsibility to lower levels within central government ministries or agencies (Randinelli et al (1984). This signifies shifting workload from central located officials to staff of or offices outside the national capital (ibid, 1984). In this respect it is shifting from city headquarters to the Divisions and lower Councils. Fiscal decentralisation itself entails local government to have revenues to carry out decentralization functions (World Bank, 2001). On the other hand economic / market decentralization involves privatization and de-regulation, thus shifting from public to private sector (ibid, 2001). These forms overlap and are mutually inclusive.

The common modes in which these forms are operationalized include deconcentration where there is redistribution of decision making. Then there is delegation which involves transfer of responsibility or decision making and management to the lower levels, and devolution where certain functions and decisions are relinquished to the lower levels (Ahmed et al, 1998; UN-Habitat, 2013). This last nature is considered as the 'true' decentralization (Ahmed and Bird, 1998). The essence therefore is that government reduces the number of tasks performed by central government.

Consequently, the transfer of decisions-making and service delivery endows the central government with the time and resources to concentrate on management of major functions or programmes while the local issues are left to the local government. One of the tiers of local government in Uganda where decentralization is extended is the municipality level with the objective of improving municipal management functions like urban planning.

\subsection{Problem Statement.}

Decentralised urban planning has been in place since 1964 under the then Town and Country Planning Act Cap 30. This is because some planning powers had been delegated to Local Authorities then known as 'planning committees' that included Kampala City Council.. Although the 1995 Republic of Uganda Constitution put in place 'Decentralization Policy' that contained a mixture of 'devolution and deconcentration', intended to move away from the centralized top-down, the system has largely not operated effectively. Even the decentralised 
urban planning adopted under Kampala Capital City Act, 2011 has in practice not been operationally effective due to a number of constraints and challenges.

\subsection{Objectives of the paper}

The objectives of the paper are:

i). To highlight the genesis of decentralized urban planning in Uganda and Kampala Capital City.

ii).To outline the decentralized urban planning operation system,the constraints and challenges

iii).To Recommend strategies to be adopted for effective operationalization of decentralized urban planning.

\subsection{Methodology of study}

The study was undertaken in Kampala Capital City as part of the broad investigation on 'Urban Planning and Development control: A Case study of Kampala Capital City, 2004-2016' for Doctoral Thesis. Decentralization of development control was identified as a key strategy in operationalizing urban plans implementation. The study design applied a multi-source inquiry using more of qualitative than quantitative research methods.

The data was collected from three administrative Divisions of Kampala Capital City that included Kawempe, Makindye and Central. The methods of collection included documents review; field observations of processes at grass roots level; key informant interviews; household interviewees who are land owners and focus group discussions. Although 100 households were targeted however response was received from only 80 interviewees and 30 key informants. While a random survey was used in selecting target interviewees, purposive sampling technique was applied to select key informants.

\subsection{Decentralization Practice in Uganda.}

In 1987, the Government in power known as the 'National Resistance Council' (NRC) enacted the Resistance Council and Committees Statute which gave them political, administrative, financial, planning and judicial powers (Independent Publications Limited, 2014:12). These Councils took charge of management, development and welfare of people in their localities. Later in 1992 the President of the Country launched the Local Government Decentralization Programme, followed by Local Government (Resistance Council) Statute 1993 that emphasized greater Local Government autonomy and authority (ibid, 2014: 12).

Decentralization of local government system came into effectthrough the 'Constitution of the Republic of Uganda 1995'. Chapter Eleven of Local Government, 'Principles and Structures of Local Government', Article 176 in the Constitution states as follows:

(1). The system of Local Government in Uganda shall be based on the district as a unit under which there shall be such lower local government and administrative units,

(2). The following principles shall apply to the local government:

a) The system shall be such as to ensure functions, powers and responsibilities are devolved and transferred from the Central Government to local government units in a coordinated manner,

b) Decentralization shall be a principle applying to all levels of local government and in particular from higher to lower units to ensure peoples' participation and democratic control in decision making,

c) The system shall be to ensure the full realisation of democratic governance at all local government levels,

d) There shall be established for each local government unit a sound financial base with reliable sources of revenue,

e) Appropriate measures shall be taken to enable local government units to plan, initiate and execute policies in respect of all matters affecting the people within their jurisdiction.

The provisions of the Constitution Article 176 are operationalized by the Uganda Local Government Act Cap 243 specifically under Part II-Local Governments that identifies the categories of local government and administrative units which include: local governments in a district rural area, and local governments in a City.

Part II of the stated Act identifies the City (Kampala) as being equivalent to a district thus mandated to exercise all functions and powers conferred upon it within its area of jurisdiction. The City Division is equivalent to the Municipality, while Municipal Divisions and Towns equivalent to a sub-county. Hence the Divisions and lower councils are part of lower local government system, and carry functions spelt out for municipality and Town council respectively.

At the same time, the second Schedule, Part 5 (A), spells out the functions to remain at the City level that include approval of architectural and design standards, approval of building plans, Master, structure plans, cadastre surveys and mapping. Part 5 (B) identifies those undertaken by the Divisions and lower local governments. One of the key urban planning functions devolved to the Divisions include: neighbourhood structure plans; local land management; resolving land issues and law enforcement. 
6.0 Chronology of Decentralized urban planning in Kampala Capital City

a). Kampala City Council Land Management Policy. The continued execution of planning functions by the Department of Physical Planning (initially urban and regional planning) in the Ministry of Lands, Housing and Urban Development, meant that the then City Council did not have effective urban planning control. Similarly, management of planning and land became increasingly difficult in the face of fast growing demand for services for a well-planned city with controlled development. This meant that this decentralisation in form of delegation did not go down to the grassroots as planning decision making remained top-down process. The communities and other interest groups at the lower levels did not participate in planning decision making and were denied democratic right to debate on plans that affected them an argument put forward under collaborative, communicative and Advocacy theories (Sager, 1994; Innes, 1995; Healey, 1992; Fisher and Forester, 1993 and Davidoff, 1965).

Therefore in 1989, City Council resolved under Minute 05/32/89 of June 1989 (KCC, 1989) to appoint a 'Land Management Committee' charged with the task of working out and recommending to Council proposals on 'Land Management and Planning Policy'. The policy had the following objectives:

(i) To bring fairness, orderliness and credibility in land management and planning practice and procedures; (ii) Harness documentation and processing operations;

(ii) To harness land documentation and processing operations,

(iii) To put controls on plots on public land by eliminating middlemen and speculation;

(iv) To decentralize land management and planning from the National Department of Physical Planning;

(v) To educate the public on planning and land management and process of acquisition.

Consequently, a number of recommendations were made under this policy but implementation remained problematic. This was attributed to a number of factors that included; one, the lack of serious follow up by City Council management and Political wing; and, two, opposition to this decentralization move from those agencies that still natured centralization. However, one key recommendation that City Council adopted expeditiously was the elevation of the then urban planning unit that operated under City Engineer and Surveyor's Department, to a fully-fledged 'Department of Urban Planning and Land Management'. which was later incorporated in the restructured City Council Administrative set up in 1994.

The Department was charged with urban planning, land surveying, land management and development control. However, these functions remained at the headquarters which was a form of 'decentralized-centralized planning' or deconcentration form of decentralisation. Urban planning decisions and functions were partly removed from central Government Ministry and retained at City Council headquarters but never devolved to the grass level in the Divisions and Parishes.

\section{b) Kampala Urban Study: The Kampala District Structure Plan 1994-2004}

The Kampala Urban Study in 1994 led to the preparation of the 'The Kampala District Structure Plan 19942004' that replaced the 'Kampala Development 1972'. This plan was prepared along the concept of decentralized urban planning, and simultaneously aligned to the administrative hierarchical structure of City council. The hierarchy was composed of City Council headquarters at the top, followed by the Divisions, then Parishes and Local Councils (L.C.1s) which was the lowest tier. This decentralized urban planning framework is illustrated in Fig.1

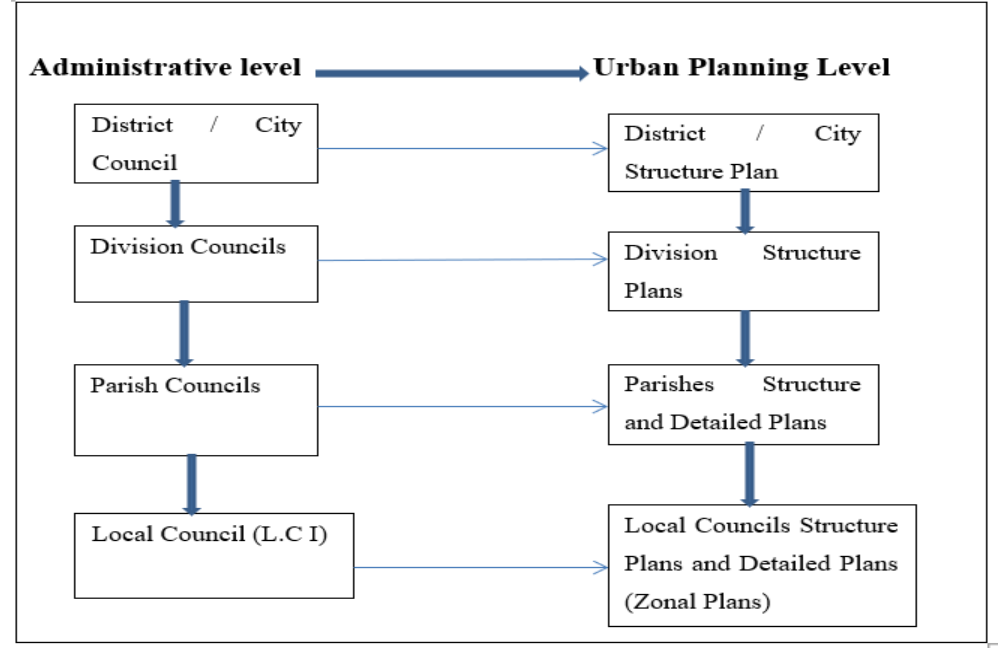

Fig. 1: Administrative and Decentralised Urban Planning Framework

Source: Kampala Urban District Structure Plan 1994-2004, Kampala City Council, 204.

Following this planning structure, the personnel for urban planning and land management were 
decentralized to the Divisions. The Divisions took charge of the defined 'forward and development control planning' and local land management. The centre remained with handling policy issues, monitoring planning performance and reviewing operations in the Divisions. This was in line with the set-up of institutional and administrative objectives which were:

i) To strengthen the institutional capacity by supporting Uganda's policy of decentralized local urban management

ii) To identify planning and action programmes which can be implemented and monitored by Kampala City Council working in collaboration with appropriate local councils.;

iii) To ensure that planning proposals and policies address the full range of socio-economic groups including lower income groups resident in Kampala (Nostrand, 1994).

These objectives were aligned to the administrative objectives that included:

i) To provide a decentralized programme of planning administration that could encourage field involvement of communities;

ii) To reinforce the Division-Parish structure and explore its adoption as an implementation framework;

iii) To encourage on going public participation in planning.

\section{d) Kampala Capital City Act 2011}

The enactment of Kampala Capital City Act 2011 changed the status of Kampala as an administrative District and made it to be part of the urban local government system. The city name changed to 'Kampala Capital City Authority' and the administration was placed under direct control of the Central Government. However, in spite of the stated changes, the organisation has maintained the administrative structure and functions of a local government that includes a decentralized urban planning and land management set up by Section 20 Lower Urban Councils of the Kampala Capital City Act. 2011. The hierarchical planning structure is maintained as indicated in Fig 1, and it is along these structures that urban planning is legally aligned.

However, under the same Kampala Capital City Authority Act.2011, a Metropolitan Physical Planning Authority was created that is mandated with preparing the Physical Development Plans for Kampala Capital City and the surrounding towns within the delineated Kampala Metropolitan Area as indicated in Map. 1. The towns in the Metropolitan Area include Kampala Capital City, Mpigi, Mukono, Entebbe ,Nansana, Makindye Ssabagabo and Kiira Municipal Councils. The functions of the Metropolitan Authority include planning, transportation, infrastructure, approving the Capital City Broad Physical Development Plan and beautification of the towns within.

Map 1. Kampala Metropolitan Area

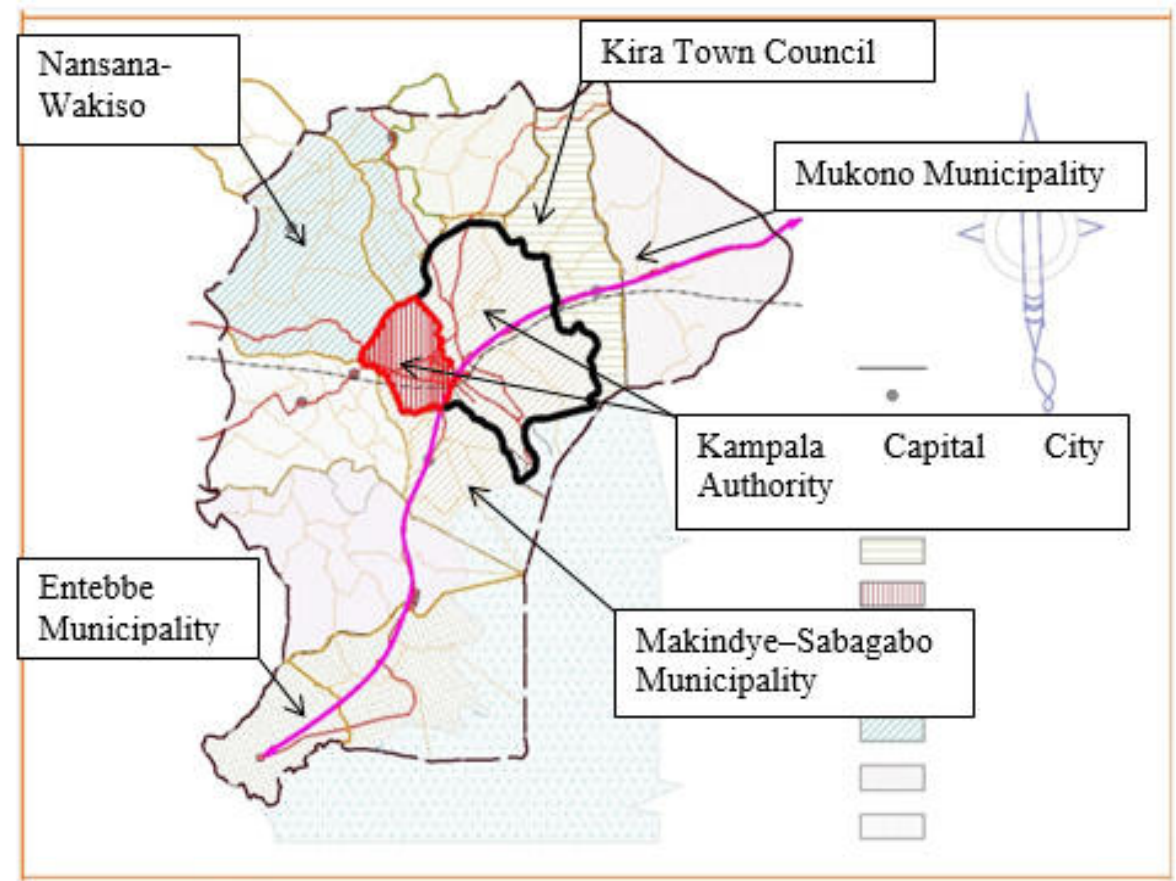

Source: Redefinition of Kampala City Boundaries Report 2009, (Ministry of Local Government).

Under the same Act, the Divisions are given responsibility to prepare Neighbourhood Structure Plans, local land management, and resolving with preparation of neighbourhood Structure Plans, local land management and resolve local land issues. This is in conformity with the provisions of the Uganda Local Government Act Cap 
243 and the National Physical Planning Act 2010.

\subsection{The Challenges of Decentralized Urban Planning}

A number of challenges have occurred since the launch of decentralised urban planning in Kampala City Council under the then 1964 Town and Country Planning Act Cap 30, and the now Kampala Capital City Authority era, since 2011. These include: Institutional; top-management autocracy; not wanting to let go and remaining accountable to the centre and undermining lower councils; limited technical capacity and logistics; poor financial situation; political chauvinism and high jacking planning powers at lower levels; poor communication and gaps in collaborative planning; corruption and lack of good will by central government.

i) Institutional Challenges. One challenge that persistently confronted the then City Council and is still faced by the Kampala Capital City Authority is vertical decentralization. Watts (1992:160) points out that this form of decentralization just complicates the process of public administration by adding several agencies to the decision making process. In Kampala City then, urban planning was one of those areas that the divisions had to take on and add to the web of the many areas they had to tackle. The Divisions had not been prepared for this load of functions nor had they any experience in coordinating the planning decisions neither with the headquarters nor with the lower tiers.

ii) Inadequate manpower and logistics for planning . Inadequate capacity at the Division and lower local levels to handle new planning responsibilities continues to pose a challenge to the decentralization process. When planning and land management was centralized in 1994, City Council had limited technical capacity in planning and the allied fields as land surveying, land management and valuation surveying which had been incorporated in the Department of Urban Planning and Land Management.

At the time of decentralization, the headquarters had only 2 Physical Planners, 1 Land Surveyor and 2 Assistant land surveyors, 1 Land Officer and 3 Assistant land officers and 2 Geographers. The Divisions and lower local Councils did not have such cadre of personnel. Thus by 1995 the number of Planners was increased to 7 with each Division getting one Planner. The other officers could not be decentralized as they were too few to cover all the Divisions. Even by the period of 2014 / 2016, Kampala Capital City Authority had limited capacity in planning and the allied fields such as land surveying, land management and valuation surveying that had been incorporated in the Department of urban planning and land management. The Divisions continue to have one Planner each in spite of the increased population to serve in each Division with a ratio of about 1:300,000 people. Other disciplines as surveyors, land officers are still not represented. .

This challenge still persists at the Divisions which have thin urban planning personnel and in most cases with one physical planner in a Division. The Parishes do not have this calibre of personnel and hence the communities have most of the time to rely on non-professional planning personnel as a fall-back position indicated in Table 1 trough Research findings. The findings indicate that the Enforcement officers and Local Council 1 officials are on the lead of providing planning guidance.

Table 1: Officers who provide Guidance on planning

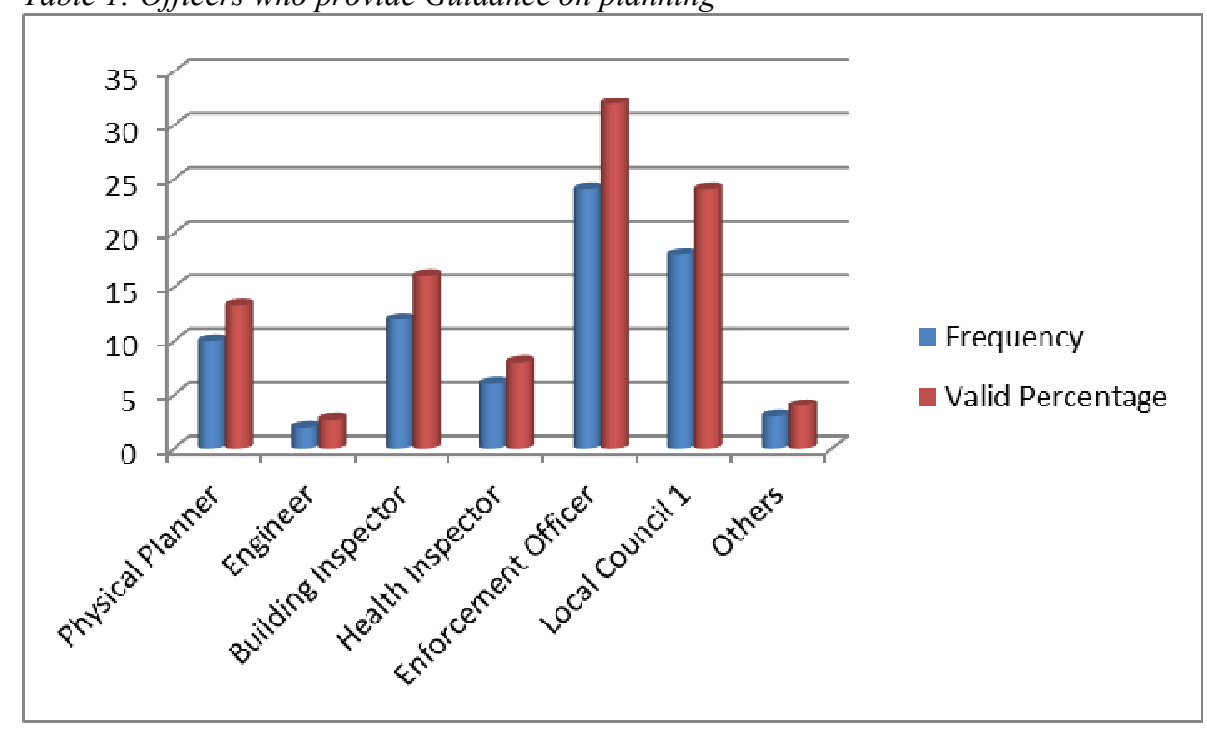

Source: Author's Field data, (2014).

The situation was exacerbated by the absence of established planning operational offices at both the Parishes and Local Council levels. Even at the Divisional level the decentralized urban planning personnel had to share the available offices. To date the situation has not improved. The decentralized urban planning offices are 
not equipped with planning tools, drawing equipments, computers and requisite software; paper for drafting, maps, tracing and printing. They also don't have attached vehicles for routine and field work exercises. Thus, the decentralized planning units have to depend on the centre for logistical support which Lewis, (2014) views as 'fostering dependency' in terms of administrative centralization.

iii) Top management autocracy: not let go syndrome. Research study findings (2014) on 'Development control and Plan implementation' by Barugahare, J.B, reveal that since 2012, the headquarters at City Hall has taken over the majority of the Divisions' planning functions. This is not the official policy of Kampala Capital City Authority but a top management decision which is outside the provisions of Kampala Capital City Act. 2011. Consequently, those devolved planning functions to the Divisions such as endorsing development applications for land, land sub-division processing and consent, change of user and preparation of local area physical plans are now recentralised to the headquarters. Even the issues of land disputes and inquiries on planning and development are also directed to the headquarters.

The challenge of planning autocracy is also associated with forces that support centralized urban planning including top bureaucrats who still remain accountable to the centre. In the initial Kampala City Council, the technocrats within the now Directorate of Physical Planning were reluctant to decentralize urban planning and land management because they would lose the planning control over the city and thus 'not want to let go syndrome'. In the same manner the technocrats at City Hall did not seem willing to move to the Divisions where facilities to execute planning functions were non-existent. This was reinforced by a mind-set and perception that the centralized urban planning system was stronger and effectively regulated and thus more workable.

This attitude frustrated the decentralization process to execute the provisions of the '1994-2004 Kampala Structure Plan'. To date this mind-set challenge still prevails although more pronounced at the top KCCA backed by the technocrats at the headquarters. They have consequently remained at the headquarters. The majority of the planning functions which should have been carried out by the Divisions.

This behaviour is impacting negatively on the implementation of the provisions of the current'Kampala Capital City Physical Development Plan 2012'. The physical planners at the Divisions have to wait for planning directives from the headquarters to implement the provisions of the current plan. Unfortunately however, during the time of waiting unauthorized development continue taking place outside the planning framework.

Rondinelli et al, (1984) point out that, "centralization has tended to be the ideal and the norm because of the former colonial system inherited. Central agencies are unwilling to give up authority, and staffs are still loyal to the centre". This challenge is posing a threat to decentralization efforts of urban planning within Kampala Capital City. As Fisher (2007) points out, this is a case where there is decentralized administrative function without devolving the power to make meaningful decisions. The stake holders still face the challenge of not being able to set their own objectives other than implementing what is directed to them from the centre. Similarly, the usurping of the decentralization functions by top management and technocrats at the headquarters is a denial of local participation in decision making and the democratic right instituted under the constitution. Nabukeera, M. et al (2015), agree that by acting in this manner the central Government is pocketing peoples' right given to them by the Constitution of Uganda. This increases bueurocracy of top-down decision making and and causes delays in getting planning actions. Research carried out indicates that it takes over 12 months to get response on planning inquiries as indicated in Table 2.

Table 2: Duration of response for inquiries

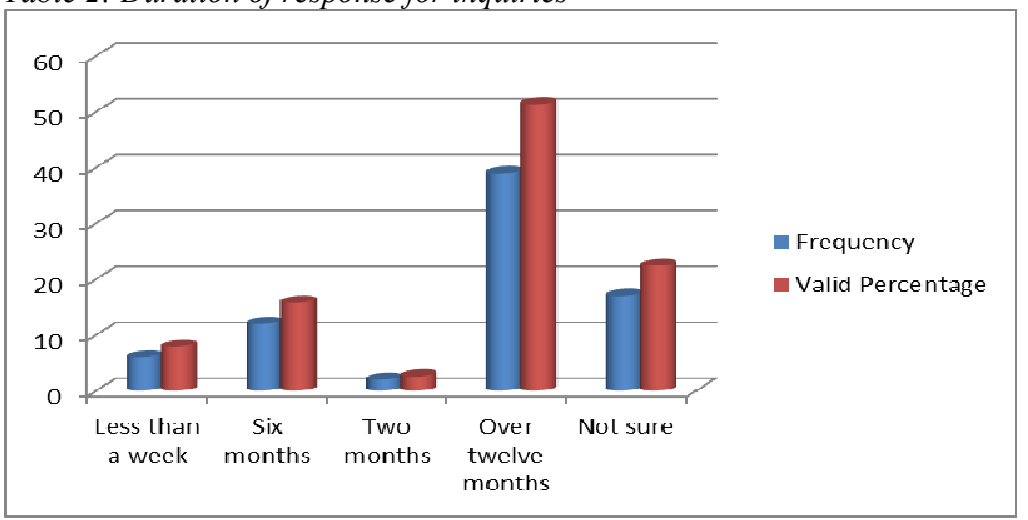

Source: Author's Field data, (2013).

vii) Ignoring local levels challenge. There is a tendency of different interests to ignore by pass the lower levels and seek advice from higher levels. This is quite common with the private sectors who want their development applications or approvals handled expeditiously $\mathrm{n}$ when even the required information for decision making has not been obtained. Quite often such developers want to evade planning requirements and want to use the higher 
levels to give directives to lower local councils to grant themconsent or change the plans in their favour. Research findings (Table 3) reveal a category of those who influence change of plans and those who pay money rank highest.

Table 3: Category that Influence change of Plans.

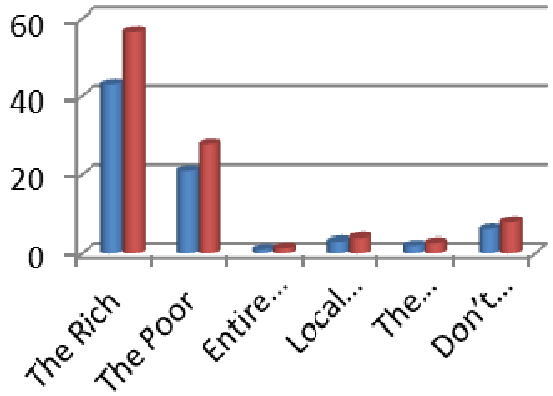

Frequency

Valid Percentage

Source: Author's Field Data, 2014

iv) Poor financial resources challenges. The Capital City Authority faces the challenge of inefficiencies in widening the resource base envelope from which it can finance urban planning equipments and tools required at the Divisions. This also results in inability to finance the general planning operations and implementation of decentralised planning proposals of the current Physical Development Plan 2012. For instance the Kampala Capital City Authority budget for Urban Planning for Financial year 2009/2010 (KCCA, 2011) was 194 Uganda Shillings (US\$.75.000) but only 24 Uganda million shillings (US \$.9.000.) and most of this was used to execute planning activities at the centre. The persistent poor financial resources continue to constrict recruitment of man power and the urban planning sector is hit hardest at the Divisions..

However, UNCHS-(Habitat) points out that decentralization in some countries, including Uganda, are a sign of dis engagement that means commitment to implement the former. At the same time it is pointed out that if there is no devolution of resources as required decentralization will not be effective. For Kampala City, there has not been significant transfer of concomitant funds overtime to enable the Divisions and Lower councils perform the specified urban planning functions.

v) Political Chauvinism over urban planning considerations. Administrative decentralization through devolution has been misinterpreted by local politicians as having authority to direct operation of services. Consequently there has been a tendency to direct the technical officers including urban planners to sanction developments that don't even conform to the provisions of the physical plans. Such moves tend to favour the people's interests in the politicians' constituencies. The Planners' professional decisions may threaten the local politicians' desires to please the local communities' interests which in turn puts at stake the local politicians' votes. Consequently the politicians' decisions tend to prevail over the technocrats' advice.

vi. Poor Communication and planning gaps. Inadequate communication flow on planning and development intentions continue to pose serious challenges on implementation of the decentralization process. It is further exacerbated by lack of collaborated planning approach between the controlling authority, Kampala Capital City headquarters, the Divisions, and the stakeholders. The implications are that the local leadership and communities cannot effectively and collectively participate in planning decision making on matters affecting their local areas which makes them feel that they do not own the resultant plans. Research evidence indicates that $68.4 \%$ of the interviewees (Table 4 ) never get communication on spatial plans for areas where they live or operate businesses because the Planners rarely consult the local communities on how they want to see their areas developed. This is often tantamount to the plans being rejected as have little or no community contribution and besides the communities would have already undertaken their developments. 


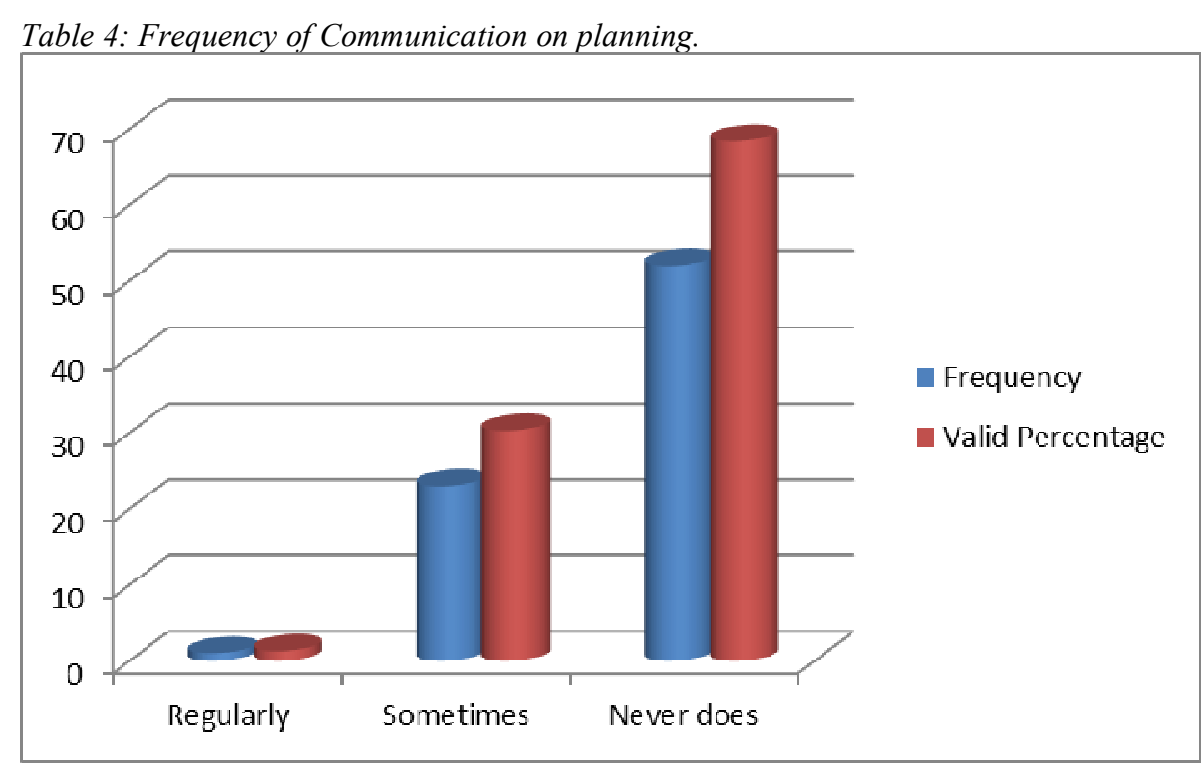

Source: Author' Field data (2014)

vii. Corruption with decentralized urban planning. The decentralized system is accused of promoting corruption through collaboration between technocrats and politicians at local level of planning. This often involves exchange of money as evidenced by research findings in Table 5. Decentralization being a new concept has had such flaws that water down the essence of providing services efficiently and expeditiously at the lower levels. This does not negate the view that there is no corruption under a centralized system, but the findings indicate what was found out at the time.

Table 5: Action taken when Development requirements are evaded

\begin{tabular}{|l|l|l|}
\hline Responses & Frequency & Percentage \\
\hline Illegal developments & 1 & 1.25 \\
\hline Give money when caught and don't demolish & 39 & 48.75 \\
\hline Don't break unless on major road reserve & 1 & 1.25 \\
\hline Carry building equipments when have no money & 3 & 3.75 \\
\hline No response & 7 & 8.75 \\
\hline Demolish & 23 & 28.75 \\
\hline Taken to court & 6 & 7.50 \\
\hline Total & 80 & 100 \\
\hline
\end{tabular}

Source: Author's Field data,( 2013).

Corruption is evidenced by high percentage of respondents who pay money to get away with punitive actions that would be taken on evasion of the planning requirements. No reviews have ever been undertaken to identify the weaknesses and put the system on an efficient operational course. This corruption challenge is now being advocated by Kampala Capital City management for recentralising urban planning to bring it under effective control.

\subsection{Recommendations}

The following suggestions are presented to improve the decentralization processes of urban planning.

a). Decentralized urban planning needs to be effectively aligned to administrative, political and financial decentralization if it has to work

b) Decentralization should be viewed as a basis for democratic human rights where communities must participate in planning decision making that affect them. This means involvement at all tiers of planning stages that include broad physical plans; Detailed Plans and Area action Plans.

c) Urban Plans at all levels need to be prepared and made relevant to stakeholders needs. A cardinal issue of focus should be the local conditions and particularly the informal sector in housing and business activities.

d) The Parish and Local Council I's need to be brought within the legal Urban Planning framework. These tiers should be part of the statutory urban planning structures with legal mandate to check and ascertain the physical developments going on.

e)Understandable and less complex planning language should be used in plans preparation processes to enable locals understand and participate, to minimize technocratic rationalism where planning language is only 
understood by the Planners and becomes a dogma to the rest of the communities..

f) Decentralized funding at the lower levels should be a requirement for this mode of governance to take into account of the decentralized urban planning as one of the key functions to be funded. The funds need to be budgeted for preparation of a range effective urban planning operations. Continued reliance on the Headquarters for regular releases of funds not only delays operations but also the spirit of decentralization. Along with this is equipping the planning units with the necessary planning tools as drawing equipments, drawing tables, tape measures, computers with requisite planning and design software and field vehicles.

g) Kampala Capital City Authority should recruit more Planners and allied staff, assistant land officers, surveyors, and Geographic information experts for the Divisions. This will give opportunity to the Divisions and the lower levels not only to prepare the local plans but also to handle other planning and local land management issues.

h) There is an urgent need to train Local Leaders, communities, land owners and other interest groups at Division, Parish and Local Council one levels and to regularly sensitized on less sophisticated technical planning issues and monitoring of physical sectoral developments. This is a task that has to be undertaken by Kampala Capital City Authority and the Division Councils. This strategy enhances awareness and participation by various stakeholders in urban planning at the lowers levels. Similarly, it is pertinent that the enforcement and Local Council I Officials be trained to handle defined simple planning and land management issues which can later be certified by the Division Urban Planners. This in itself hastens planning action and may minimize illegalities.

i) Decentralized urban planning in Kampala Capital City still requires political and administrative will at the centre and Division Urban Council levels. Both parties need to be committed to the vision and objectives of decentralization to convince the rest of the stakeholders to join the decentralization drive. Rahman and Islam, (2013), point out that lack of political will and sometimes arrogance of the educated elite is a threat for practice of decentralization in land use planning'

j). Decentralization needs to be linked to the areas'local economic development so that democratisation of the decision making and resources use are focused on improving the inhabitants' propelled by decentralization.

k). Spell out the mandates of different actors, vertically and horizontally since there are different actors involved in decentralized urban planning and land management processes. This is intended to eliminate areas of overlap but also minimize areas of contradiction arising.

\section{Conclusion}

From the foregone analysis it is clear that the urban planning decentralization taking place is largely in the forms of 'delegation' and 'deconcentration'. These two forms have been affected at Division Urban Councils level and have not filtered to Lower council levels. Therefore decentralized urban planning at grassroots is still minimal and ineffective.

It is farther noted that decentralized urban planning is frustrated by other factors that include: un readiness of Division urban Council to take on new responsibilities; top management of Kampala Capital City reluctance to let go the planning powers; lack of planning manpower and logistic support; very inadequate funding for planning; minimal political support on decentralization; corruption of the system being new; the big powers overlooking the local centres and running to headquarters to give directives and lack of communication to communities and collaborative planning approach. These are challenges that Kampala Capital City has to exigently focus on if the drive for decentralized urban planning is to be effectively operationalized.

Decentralization is a key strategy of getting urban plans implemented as long as the stakeholders are involved in the urban planning processes and that this enhances their livelihoods. Similarly the form of decentralization to be pursued should be 'devolution' that gives power of decision making to the communities.

\section{References.}

1. Ahmed, J. Birdin, R. and Litvack,, J, 1999. Rethinking Decentralization at the World: A Discussion Paper. World Bank

2. Amos, F.G.C. "Strengthening Municipal Government. Cities, Vol. 6 (1989) No.3 Pp. 202-208

3. Barugahare, J.B, 2013. On-going Doctoral Research Study on 'The Mismatch between Urban planning and implementation, A case study of Kampala Capital Cjty'.

4. Buthelezi, S. 2004. Decentralization and Democratization in Africa: The Political Economy of Local Government. Un published Article of the School of Public Management and Development. South Africa University of Fort Hare.

5.Rahman, S., Islam, M. A. 2013. Decentralization in Urban -Land use Planning in Bangladesh: Rationality of the Scene Behind a Screen. Planned Development: Aspired Development. World Town Planning Day 2013 : Pp 3-13.

6. Fisher, J. 2008. Devolution and Decentralization of Forest Management in Asia and Pacific, Bangkok, 
Thailand. http.// www.fao.org/doc rep / 3030e/

7. Government of Uganda , 1995. The Constitution of the Republic of Uganda 1995, Chap. Eleven. Local Government - Article 176, Pp. 117 - 118. The Government Printer, Entebbe.

8. ibid, 2011.Kampala Capital City Authority Act. 2011-Part IV, Metropolitan Physical Planning Authority; Sec. 21 - 22, Pp. 20-22. The Government Printer, Entebbe

9. ibid, 1995. Local Government Act. Cap. 243. Part II - Article 3, Local Government, (578) Government Printer, Entebbe.

10. ibid, 1964. Town and Country Planning Act. 1964, Cap 246. Part IV - Execution of Schemes, Sections 1416. (5497-5498). The Government Printer. Entebbe.

11. Kaiser, K. 2006. Analyizing the Distributional Impact of Reforms : A Practitioner's Guide to Pension, Health, Labour Market, Public Sector Downsizing, Taxation, Decentralization and Macroeconomic Modelling (Volume 2).

12. Kampala City Council, 1990. Land Management Policy Report 1990, Pp. 1-22. Kampala City Council.

13. Kampala Capital City Authority Act, 2011. Functions and Services for which the Authority is responsible for and those Functions and services to be devolved to Division Urban Councils, Pp. 61-68. Government of Uganda,

14. Lewis, J.I. (2014), When Decentralization in Africa leads to reconcentration: Sub-national State Transformation in Uganda. Regional and Federal Studies, 24, Pp. 571-588 (576)

15. Massoi,L and Norman,A.S., 2009 . Decentralization by devolution in Tanzania: Reflections on community involvement in the planning process in Kizota Ward in Dodoma. Journal of Public Administration and Policy Research Vol. 1(7), Pp. 133-140, November 2009.

16. Ministry of Local Government, 2010. National Urban Policy Development Support, Urban Situation Analysis in Uganda Report 2010: Pp. 28. Republic of Uganda.

17.Kenya School of Government, Centre for Devolution Studies, working Paper series 2015, Kenya Devolution. Pp. 4-5 .Nairobi, Kenya.

18. Nabukeera, M., Boerhanned,A., Noriza, R.A., Bwenje, M. (2015), Recentralization of Kampala City Administration in Uganda: Implication for Top and Bottom Accountability. Pp. 1-13. Sage Open, JulySeptember 2015.

19. Rondenelli, D.A, Nellis, J.R, and Cheema, G.S, 1989. Decentralization in Developing Countries: A Review of Recent Experience, World Bank Staff, Working Paper No. 581, Pp.13-28. Washington D.C.

20.Silverman, J. M, 1992. Public sector Decentralization: Economic Policy and Sector Investment Programme (Technical Paper 186), Washington: World Bank.

21.The World Bank Group, Internet Site, 2002 http://www.world bank.org/publication sector/decentralization/different.htm.

22. UN-Habitat / UNDP (2014). The Impact of Decentralisation and Urban Governance on Building Inclusive and Resilient Cities. Asia-Pacific Urbanization and Climate Change Issue Brief Series No. 2, January 2014, Pp. 1-9

23. UNHCR, 1993. Management of Human Settlements: The Municipal level, Nairobi

24. United Republic of Tanzania, 2006. Embedding Decentralization by Devolution Across Government, Strategy and Road Map. Final Draft, Dar es Salaam, Government Printers.

25. Van Nostrand Associates Ltd., 1994. Kampala Urban Study: Structure Plan 1994-2004. Pp.65-87. Kampala City Council, Uganda.

26. Watts, K. 1992. National Urban Development Policies and strategies: A Review of Country Experience in Harris, N (ed.) 1992.

27. World Bank Report, 1989. Sub-Sahara Africa - From crises to sustainable growth, 1989: Washington, USA. 